\title{
鉄系超伝導体の薄膜成長とデバイス作製
}

\author{
平松 秀典 ${ }^{*} 1{ }^{*} 2, \dagger$, 細野 秀雄 ${ }^{*} 1,{ }^{* 2}$
}

\section{Thin-film Growth and Device Fabrication of Iron-based Superconductors}

\author{
Hidenori HIRAMATSU ${ }^{*_{1},{ }^{*}, \dagger}$ and Hideo HOSONO ${ }^{*_{1}, *_{2}}$
}

\begin{abstract}
Synopsis: Iron-based superconductors have been receiving much attention as a new family of high-critical temperature superconductors since 2008 owing to their unique properties and distinct difference from cuprates and conventional superconductors. This paper reviews our research on iron-based superconductors' thin-film with an emphasis on growth, critical current properties, and device fabrication.
\end{abstract}

Keywords: pulsed laser deposition (PLD), molecular beam epitaxy (MBE), epitaxial films

(Some figures in this article may appear in colour only in the electronic version)

\section{1. はじめに}

我々の研究グループは、ワイドギャップ $p$ 型半導体 $R e \mathrm{CuChO}(R e=$ 希土類, $C h=$ カルコゲン $)$ の研究 ${ }^{1)}$ から 派出して新規磁性半導体を探索している過程で、2006 年 に $\mathrm{LaFePO}{ }^{2)}$ （臨界温度 $\left(T_{\mathrm{c}}\right)=4 \mathrm{~K} ）$ が、2007 年には $\left.\mathrm{LaNiPO}^{3}\right)\left(T_{\mathrm{c}}=3 \mathrm{~K}\right)$ がバルク超伝導体であることを報告 した。ただ、この時点ではごく少数の研究者が関心を示し たに過ぎなかった。しかし、2008 年に F 添加 LaFeAsO が $T_{\mathrm{c}}=26 \mathrm{~K}^{4)}$ のバルク超伝導体であることを発表した途端に、 世界中の研究者が素早く反応した。そして一年もたたない 間に、その最高 $T_{\mathrm{c}}$ は $\mathrm{SmFeAsO}$ の $55 \mathrm{~K}$ に達した。現在、 鉄系超伝導体の母相は、化学組成比と結晶構造で分類する と、122 型の $\mathrm{BaFe}_{2} \mathrm{As}_{2} 、 111$ 型の LiFeAs、11 型の FeSe、 245 型の $\mathrm{K}_{2} \mathrm{Fe}_{4} \mathrm{Se}_{5}$ 、ペロブスカイト様の厚いブロック層を 有する $\mathrm{Sr}_{2} \mathrm{VFeAsO}_{3}$ と、1111 型の $\mathrm{LaFeAsO}$ 以外に 5 種類 見いだされている。1986 年から始まった銅酸化物高温超 伝導フィーバー以来の第二の鉄系高温超伝導フィーバーか ら約 10 年が経過した現在、その物性解明や超伝導機構の

Received July 13, 2017

${ }^{* 1}$ 東京工業大学 科学技術創成研究院 フロンティア材料研究所 干226-8503 神奈川県横浜市緑区長津田町 4259 郵便箱 R3-3 Laboratory for Materials and Structures, Institute of Innovative Research, Tokyo Institute of Technology, Mail-box R3-3, 4259 Nagatsuta-cho, Midori-ku, Yokohama, Kanagawa 226-8503, Japan

$*_{2}$ 東京工業大学 元素戦略研究センター

干226-8503 神奈川県横浜市緑区長津田町 4259 郵便箱 SE-6 Materials Research Center for Element Strategy, Tokyo Institute of Technology, Mail-box SE-6, 4259 Nagatsuta-cho, Midori-ku, Yokohama, Kanagawa 226-8503, Japan

† E-mail: h-hirama@mces.titech.ac.jp DOI: $10.2221 /$ jcsj. 52.433
解釈がめざましく進んでいる 5-7)。

その一方で、我々の研究グループは、この新物質の物性 解明にはもちろん、ジョセフソン接合をはじめとする超伝 導デバイスや薄膜線材への応用展開を進めていくためには、 高品質「薄膜」が必要不可欠であると考え、2008 年から その研究開発を進めてきた。それまでに $\mathrm{LaFeAsO}$ と同じ 1111 型構造を有するワイドギャップ $p$ 型半導体 $R e \mathrm{CuChO}$ の特異な光電子物性に着目して、エピタキシャル薄膜の作 製およびその高品質化に取り組んできた経験から、着手当 初は、 $\mathrm{ReCuChO}$ と同じもしくは類似した薄膜成長法が適 用可能と考えた。しかしながら、数多くの実験を行った結 果、エピタキシャル薄膜を得るどころか、その結晶相を 「薄膜」という試料形態で得ることすら困難であることが わかった。そこで、パルスレーザー堆積（PLD）法を用い て薄膜作製を行う上で、次の 2 点を改良した。一つは、 PLD ターゲットの高純度化であり、もう一つは PLD 法と しては一般的ではない Nd:YAG レーザーの第二高調波 （波長 $532 \mathrm{~nm}$ ）をアブレーション用レーザーとして適用す ることである。この Nd:YAG PLD（Fig. 1(a)）の導入によ り、世界に先駆けて 1111 型 $\mathrm{LaFeAsO}{ }^{8)}$ と 122 型 Co 添加 $\mathrm{SrFe}_{2} \mathrm{As}_{2}{ }^{9)} \quad(\mathrm{Sr} 122: \mathrm{Co})$ エピタキシャル薄膜を得ることに 成功した。この 122 型薄膜成長の報告を皮切りに、同じ 122 型化合物の中でも $\mathrm{Sr} 122$ よりも $\mathrm{BaFe}_{2} \mathrm{As}_{2}$ (Ba122）薄 膜の方が大気中でも安定で物性研究やデバイス・線材応用 に適していることを見いだした 10)。現在では世界中の多 くの研究グループが鉄系超伝導体薄膜の作製に成功してい るが、中でも最も研究が進んでいるのがこの 122 型 Ba122 薄膜と言えるだろう。 
1111 型 $\mathrm{LaFeAsO}$ のバルク超伝導が報告されてから来年 でちょうど 10 年を迎えようとしており、鉄系超伝導体の 薄膜およびデバイスに関する総説が既に多数発表されてお り 11-18)、本特集号でも、鉄系超伝導体の将来応用を目指 した研究の最先端をリードする多くの先生方が寄稿されて いる。そこで本稿では、我々の研究グループのこれまでの 取り組みを簡単に紹介する。

\section{Nd:YAG PLD による 1111 型化合物の薄膜成長}

一般的に、PLD 法のアブレーション用レーザーとして は $\mathrm{KrF}$ エキシマレーザーなどの紫外光が用いられること がほとんどである。しかしながら、我々は 300 バッチ以上 の実験を試みたにもかかわらず、エピタキシャル薄膜はお ろか、1111 相を薄膜として形成させることすらできな かった（一度も 1111 相由来の X 線回折ピークを観察でき なかった） 8,11)。そして、Nd:YAG PLD 法（Fig. 1(a)）を 適用することにより、(001)方位の $\mathrm{MgO} 、(\mathrm{La}, \mathrm{Sr})(\mathrm{Al}, \mathrm{Ta}) \mathrm{O}_{3}$ (LSAT)、 $\mathrm{MgAl}_{2} \mathrm{O}_{4}$ の 3 種類の単結晶基板上に $\mathrm{La} 1111$ エピ タキシャル薄膜を得ることに成功した。しかしながら、バ ルクターゲット中には $10 \%$ のフッ素を添加しているにも かかわらず、得られたエピタキシャル薄膜中にはフッ素が 一切取り込まれなかったため、超伝導転移が観察されな かった。同様な膜中へのフッ素の取り込みの難しさは、分 子線エピタキシー（MBE）の場合においても報告されて いる 19)。現在、MBE 法においては 1111 エピタキシャル 薄膜成長に日本の 2 つの研究グループのみが成功しており、 フッ素の添加方法も工夫が進んでいる 20-24)。

現在、結晶化させるために基板温度を上げた in-situ PLD 法で 1111 エピタキシャル薄膜合成に成功しているのは、

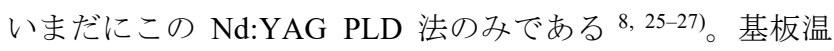
度と励起密度の最適ウインドウが狭く $8,26,27)$ 、条件最適化 に細心の注意が必要なことが、非常に少ない合成成功例数 につながっていると思われる。そして、残念ながら現在に おいても PLD 法による 1111 相薄膜の形成の難しさの要因

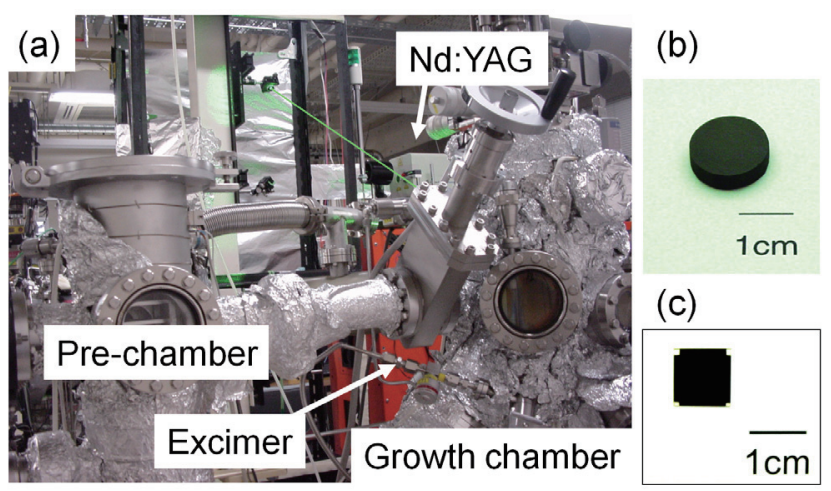

Fig. 1 (a) The Nd:YAG PLD system. (b) A high-purity $10 \%$ F-doped LaFeAsO bulk target. (c) An epitaxial LaFeAsO film. (a)

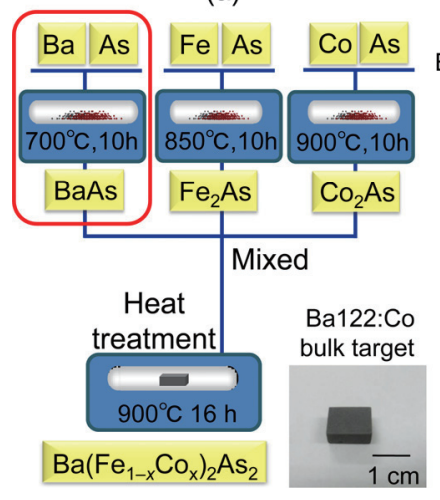

(b)

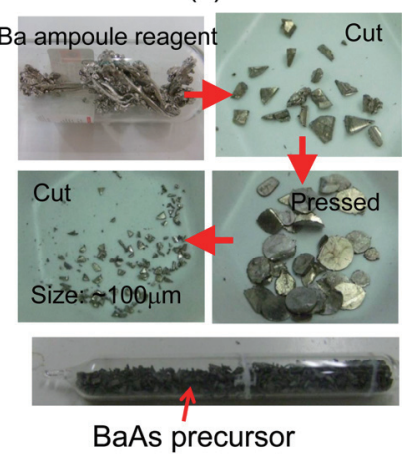

Fig. 2 (a) Synthesis process of Ba122:Co bulk PLD targets. (b) Optimized preparation procedure of a BaAs precursor powder. ${ }^{29)}$

は不明である。我々の研究グループでは最近になってやっ と、in-situ Nd:YAG PLD 法により、 $T_{\mathrm{c}} \approx 40 \mathrm{~K}$ の F 添加 $\mathrm{Sm} 1111$ エピタキシャル薄膜の合成に成功した ${ }^{25)}$

\section{122 型化合物の薄膜成長}

\section{1 Co 添加 $\mathrm{BaFe}_{2} \mathrm{As}_{2}$ （Ba122:Co）}

2008 年に最初に合成に成功した $\operatorname{Sr} 122$ 薄膜が大気中の水 分に非常に敏感であること ${ }^{10,28)}$ 、高 $T_{\mathrm{c}}$ 超伝導誘起のための 添加物として、1111 相のフッ素や 122 相のカリウムなどの 高い蒸気圧成分ではなく、高融点・低蒸気圧のコバルトが 122 相には添加物として使えることから、Ba122:Co エピタ キシャル薄膜の高品質化に取り組んだ ${ }^{29,30)}$ 。具体的には、 ターゲットの高品質化（Fig. 2, 特に前駆体となる BaAs の 合成プロセスの改善）と基板温度の最適化を行うことに よって、 $T_{\mathrm{c}}{ }^{\text {onset }}=22.6 \mathrm{~K}, \Delta T_{\mathrm{c}}=1.1 \mathrm{~K}, 4 \mathrm{~K}$ において $4 \mathrm{MA} / \mathrm{cm}^{2}$ の臨界電流密度 $\left(J_{\mathrm{c}}\right)$ を達成することができた ${ }^{29,31)}$ 。この 高い $J_{\mathrm{c}}$ 特性は、Nd:YAG PLD 法により薄膜成長中に形成さ れた $c$ 軸方向に沿った欠陥由来である ${ }^{32,33) 。(~} J_{\mathrm{c}}$ の特性比 較は 3.5 節で行う。)

Ba122:Co 薄膜の高品質成長には、単結晶基板との面内格 子不整合を緩和するために $\mathrm{SrTiO}_{3}{ }^{34)}$ や $\mathrm{Fe}$ (5) などが緩衝層 として有効であると提案されている。しかしながら、我々 が採用している Nd:YAG PLD法の場合、それら緩衝層を利 用することなく、単結晶基板上への直接成長によってほぼ 同等の結晶性と $J_{\mathrm{c}}$ を達成した。この起源に迫るため、最近 我々は、一つの PLD 成長室（Fig. 1(a)）に対して、深紫外 〜赤外領域の 4 種類のパルスレーザー（それぞれの波長： $\mathrm{ArF}=193 \mathrm{~nm}, \mathrm{KrF}=248 \mathrm{~nm}, \quad 2 \omega-\mathrm{Nd}: \mathrm{YAG}=532 \mathrm{~nm}, \quad 1 \omega-$ $\mathrm{Nd}: \mathrm{YAG}=1064 \mathrm{~nm}$ ) を適用することによって、Ba122:Co 薄 膜成長実験を行った ${ }^{36)}$ 。そして、成長速度が同じであれば 励起レーザーの波長に依存することなく、同じ品質の Ba122:Co 薄膜試料が得られることを明らかにした。それに 加えて、励起レーザー波長が短くなるに伴って、最適成長 


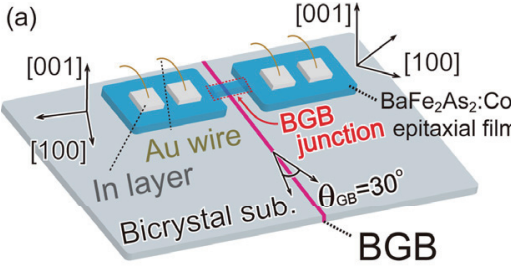

(b)
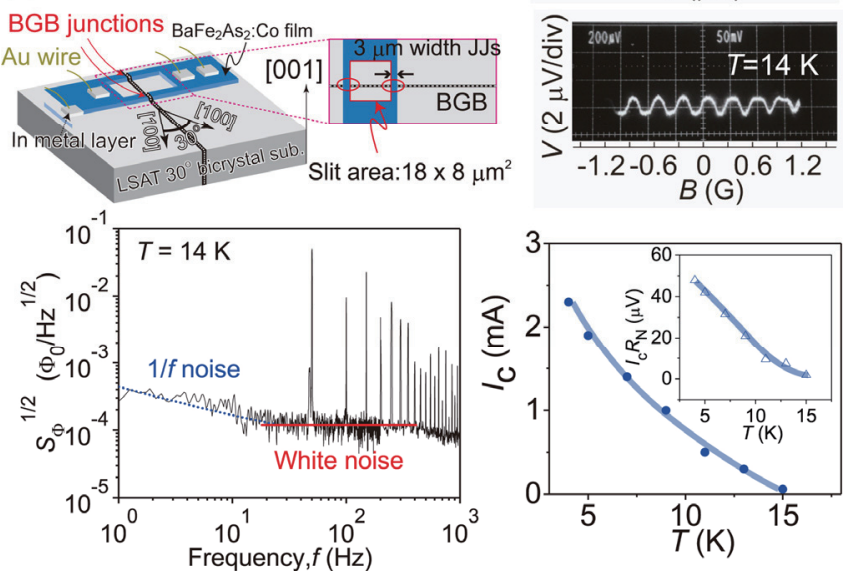

Fig. 3 Josephson junction ${ }^{37)}$ and SQUID ${ }^{39)}$ fabricated in high-quality Ba122:Co epitaxial films grown on bi-crystal substrates.

速度に到達させるために必要な励起密度が上昇することも 明らかとなった。例えば、波長 $532 \mathrm{~nm}$ の場合は $2.2-3.2$ $\mathrm{J} / \mathrm{cm}^{2}$ (入射エネルギー70 - $100 \mathrm{~mJ}$ 程度) であるのに対し、 $\mathrm{KrF}$ の場合は $6.7-10 \mathrm{~J} / \mathrm{cm}^{2}$ (200-300 mJ 程度) が必要で あった。そして、検討した中では最も短波長の $\operatorname{ArF}$ の場合 は、薄膜成長室にレーザー光が到達するまでの出力減衰の 問題で、我々の実験環境ではその最適成長速度に到達でき る励起密度まで上げられなかった。このことから、 Nd:YAG PLD 法の優位性を明らかにすることができた。そ して、あくまで我々の推測であるが、1111 相が Nd:YAG PLD 法での夕 in-situ 成長に成功していることと、この 122 型化合物に対する実験結果は関連しており、非常に高い励 起密度で実験できる環境を整えることができれば、一般的 な $\mathrm{KrF}$ エキシマレーザーでも 1111 エピタキシャル薄膜が in-situ PLD で合成可能なのかもしれない。

\section{2 Ba122:Co を用いたジョセフソン接合と SQUID}

鉄系超伝導体のジョセフソン接合は早い段階で単結晶試 料を用いて実現され、実際に対称性の議論に用いられてき た。しかしながら、弱結合とならず高 $J_{\mathrm{c}}$ を有する高品質薄 膜を利用した薄膜デバイスは害現されていなかった。そこ で我々は、高品質化に成功した Ba122:Co 薄膜を傾角 30 度 の[001]-傾斜バイクリスタル上に作製し、傾角粒界接合 (Bicrystal Grain Boundary, BGB 接合) を形成し、粒界ジョ セフソン接合 37,38 ) と超伝導量子干渉素子（SQUID） 39)を作 製した（Fig. 3)。
BGB 接合を介しない領域（つまりバルクの領域）では、 超伝導一常伝導転移に伴う急激な電圧のとびのみが臨界電 流 $I_{\mathrm{c}}=40 \mathrm{~mA}$ で観察されたのに対して、BGB 接合では $I_{\mathrm{c}}=$ $1.5 \mathrm{~mA}$ まで抑制され、一般的なジョセフソン接合に見られ る RSJ（Resistively-Shunted-Junction）型の電流一電圧特性 を示した。このことから、BGB 接合のみがジョセフソン接 合として動作していることが確認できた。さらに、弱い外 部磁場 $(0.9 \mathrm{mT})$ を印加すると、 $I_{\mathrm{c}}$ がほぼゼロに抑制され、 95\%の変調があり、ジョセフソン電流が主であることも確 認した (Fig. 3(a))。得られた BGB 接合の $I_{\mathrm{c}} R_{\mathrm{N}}$ 積は、代表 的な銅酸化物 $\mathrm{YBCO}$ より 2 桁程度低かった。また、接合抵 抗 $R_{\mathrm{N}} \mathrm{A}$ 值も $\mathrm{YBCO}$ のジョセフソン接合より 1 桁以上低 かった。

この BGB 接合形成技術を利用し、粒界ジョセフソン接 合の特性をより詳細に評価するため、バイクリスタル基板 上の Ba122:Co 膜に対して、SQUID ループ（接合幅: $3 \mu \mathrm{m}$ 、 ループ面積: $\left.18 \times 8 \mu \mathrm{m}^{2}\right)$ が 2 つの BGB 接合を通るように加 工を施した (Fig. 3(b))。14 K での電圧一磁束 $(V-\Phi)$ 特 性では、SQUID として典型的な、印加磁場に対して周期的 な電圧変調が観察され、最大電圧振幅 $\Delta V$ は $1.4 \mu \mathrm{V}$ であっ た。また、磁束ノイズ $S_{\Phi}^{1 / 2}$ の周波数依存性において、20 $\mathrm{Hz}$ 以上では、周波数によらず一定なホワイトノイズを示し、 $20 \mathrm{~Hz}$ 以下では、周波数の逆数に比例する $1 / f$ ノイズを示し た。ノイズレベルは、ホワイトノイズ領域で $7.8 \times 10^{-5}$ $\Phi_{0} / \mathrm{Hz}^{1 / 2} 、 1 \mathrm{~Hz}$ では $4.2 \times 10^{-4} \Phi_{0} / \mathrm{Hz}^{1 / 2}$ であった。これらの 值は YBCO を用いた SQUID よりも一桁高いレベルであっ た。

$I_{\mathrm{c}} R_{\mathrm{N}}$ 積はジョセフソン接合の性能指数であり高いほど高 性能と言える。SQUID のノイズレベルは低いほどよい。し かしながら、以上の結果は鉄系超伝導体が内因的に金属的 なバリア層を有することに由来していると思われる。

\section{3 Ba122:Co の粒界特性}

鉄系超伝導体は、その発見直後、超伝導とは相性が悪い と信じられてきた大きな磁気能率をもつ鉄を含むにもかか わらず、ヒ素と組み合わさることで高い $T_{\mathrm{c}}$ で超伝導を示す という意外性に注目が集まった。その後の研究で $50 \mathrm{~T}$ を大 幅に超える高い上部臨界磁場と小さな異方性因子（ $\gamma=1 \sim$ 2）が明らかとなり、高磁場において高性能な超伝導線材 への応用が期待されるようになった。

線材応用を目指した研究を行う際に最も重要な点は、そ の対象物質の粒界特性である。現在、最も研究が進んでい るY 系銅酸化物の場合は、その粒界が形成する傾角が $3 \sim$ 5 度を超えると急激に $J_{\mathrm{c}}$ が隇少し始める。そのことから、 その結晶の面内配向度を 5 度以下に厳密に抑制するため、 高精度な結晶配向制御技術の適用が必須となっており、高 コスト化・製造の長時間化の原因となっている。すなわち、 鉄系超伝導体の線材応用を目指寸ためには、その粒界特性 を明らかにすることは急務であった。 
(a)

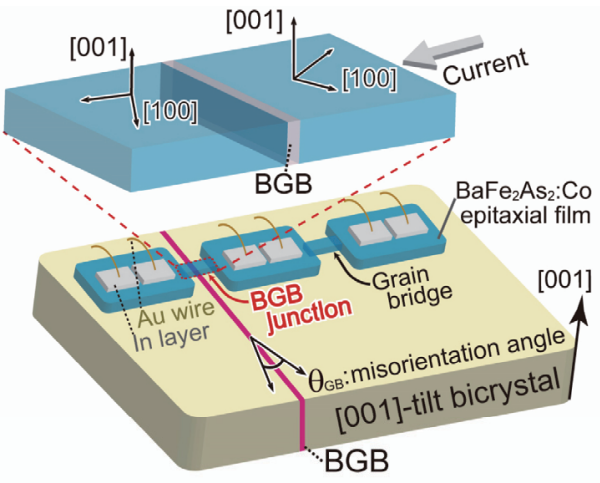

(b)

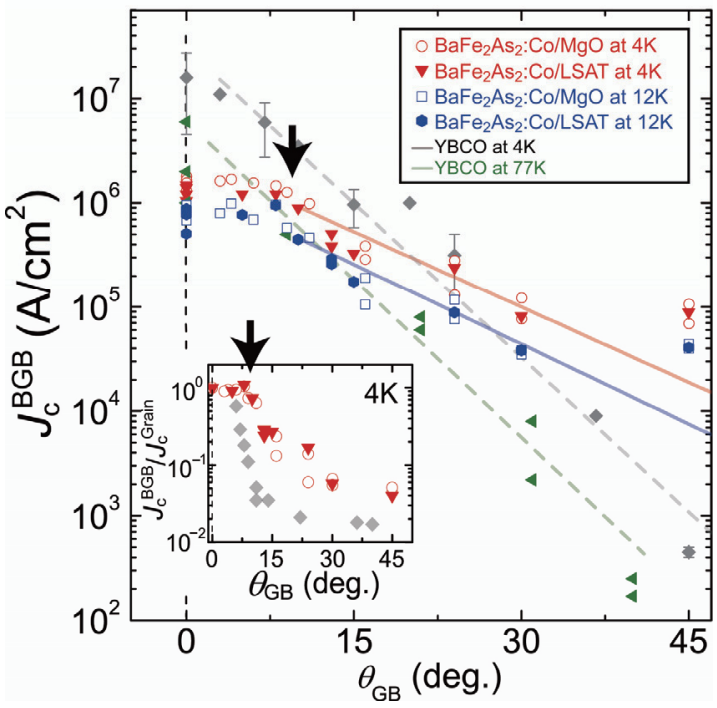

Fig. 4 Grain boundary properties of Ba122:Co. (a) Illustration of a bi-crystal grain boundary (BGB) junction. (b) $J_{\mathrm{c}}$ at $\mathrm{BGB}\left(J_{\mathrm{c}}^{\mathrm{BGB}}\right)$ as a function of grain boundary angle $\left(\theta_{\mathrm{GB}}\right){ }^{38)}$

そこで我々は、これまでに最適化してきた Nd:YAG PLD 法を用いることによって、 $\mathrm{MgO}$ と LSAT のバイクリスタル 基板上に、高品質 Ba122:Co 薄膜を作製した。そして粒界 に特性を明らかにするため、 $\theta_{\mathrm{GB}}=3 \sim 45$ 度の傾角粒界を介 する部分に BGB 接合を作製し、電流一電圧特性からその 傾角粒界における $J_{\mathrm{c}}\left(J_{\mathrm{c}}^{\mathrm{BGB}}\right)$ を測定した（Fig. 4） ${ }^{38)}$ 。その 結果、 $J_{\mathrm{c}}{ }^{\mathrm{BGB}}$ は 9 度の傾角（図中矢印の位置）まで 1 $\mathrm{MA} / \mathrm{cm}^{2}$ 以上の高い值を保持することが明らかとなった。 この臨界角 $\theta_{\mathrm{c}}=9$ 度という值は、銅酸化物の代表例である $\mathrm{YBCO}$ の $\theta_{\mathrm{c}}(3 \sim 5$ 度）と比較して約 2 倍と大きい。また、 高い傾角側で $J_{\mathrm{c}} \mathrm{BGB}$ が減少する割合にも銅酸化物と違いが あることがわかる。その結果、 $\theta_{\mathrm{GB}}=30$ 度以上の高傾角粒

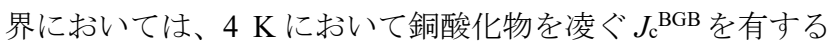
ことがわかった。その後、11 型の $\mathrm{FeSe}_{0.5} \mathrm{Te}_{0.5}$ においても、 同等の $\theta_{\mathrm{c}}=9$ 度が報告され 40$)$ 、鉄系超伝導体の優れた粒界 特性が明らかになってきている。

これらの結果は、鉄系超伝導体は銅酸化物よりも高い $\theta_{\mathrm{c}}$ を有することから、線材にする際には低いスペックである (a)

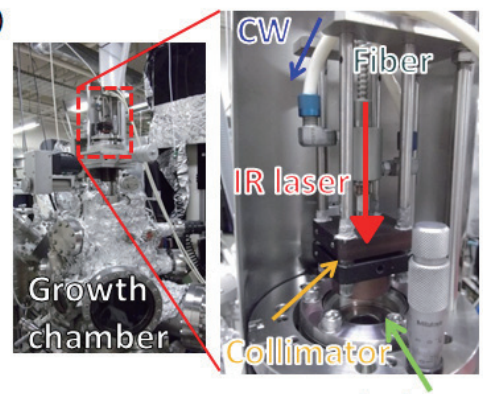

Window

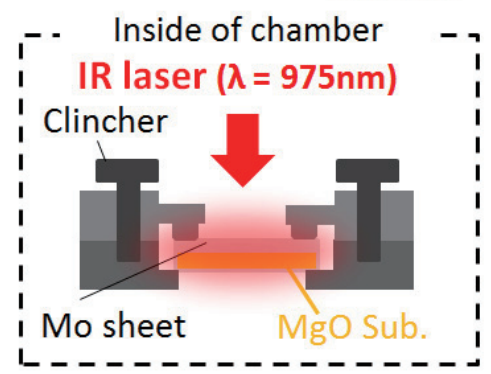

(b)

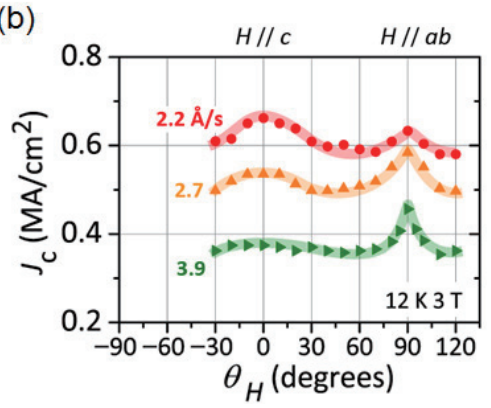

Fig. 5 (a) Substrate heating system using a semiconductor laser diode for epitaxial growth of Ba122:P thin films. (b) $J_{\mathrm{c}}$ of Ba122:P epitaxial films grown at different growth rates as a function of external magnetic field angle $\left(\theta_{\mathrm{H}}\right){ }^{42)}$

9 度以下の面内配向度でよいことを示唆しており、実際に 最大 7 度の面内配向度の比較的質の悪い金属テープ基板を 採用した場合でも、 $J_{\mathrm{c}}$ はどれも単結晶上の試料と同等の 1 $\mathrm{MA} / \mathrm{cm}^{2}$ を超える高い值（最大 $3.5 \mathrm{MA} / \mathrm{cm}^{2}$ ）を示した ${ }^{41)}$ 。

以上の結果により、鉄系超伝導体は、面内配向度が 9 度 以下のテープ基板を使えば、高い $J_{\mathrm{c}}$ を示寸薄膜線材の作製 が可能であることが明らかになった。将来の製造コストを 考えると、鉄系超伝導の優位点と言えるであろう。

\section{3. $4 \mathrm{P}$ 添加 $\mathrm{BaFe}_{2} \mathrm{As}_{2} \quad(\mathrm{Ba} 122: \mathrm{P})$}

高性能線材の実現を目指して、より $T_{\mathrm{c}}$ の高い $\mathrm{P}$ 添加 Ba122 薄膜（Ba122:P, バルクの最大 $T_{\mathrm{c}}$ は $31 \mathrm{~K} ）$ の薄膜成長 条件を探索した ${ }^{42,43)}$ 。まず、Ba122:Co よりも高い成長温 度が必要となったことから、Ba122:Co の際に採用していた、 一般的なランプ加熱方式を、自ら設計した半導体レーザー 加熱システムへ変更した（Fig. 5(a)）。その結果、Mo 製の 背板を介して面内均一性の高い最大 $1400^{\circ} \mathrm{C}$ の成長温度を 達成した。そして、Ba122:P の最適成長温度は約 $1050^{\circ} \mathrm{C}$ と、 Ba122:Co（800〜850 ${ }^{\circ} \mathrm{C} ｛ }^{30)}$ より $200{ }^{\circ} \mathrm{C}$ 程度高いことを明ら 

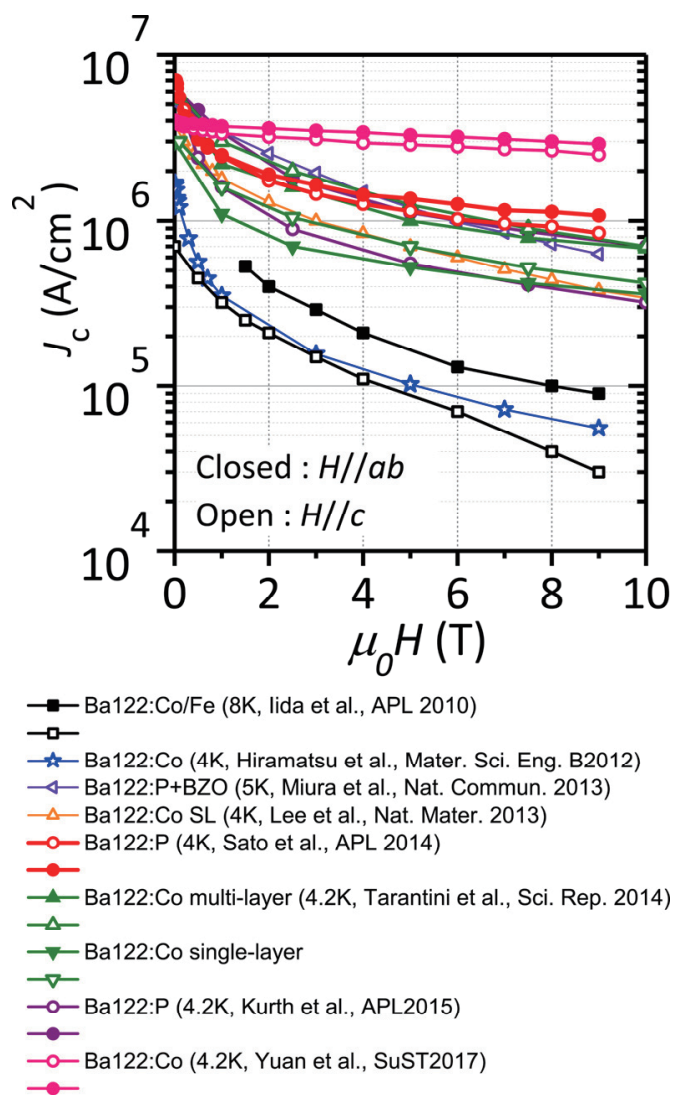

Fig. $6 J_{\mathrm{c}}$ of various Ba122 epitaxial films under external magnetic fields. ${ }^{31,42,48-53)}$

かにした。 $T_{\mathrm{c}}$ は期待通り、Ba122:Co よりも上昇し、 $T_{\mathrm{c}}{ }^{\text {onset }}=$ $26.5 \mathrm{~K}, \Delta T_{\mathrm{c}}=1.5 \mathrm{~K}$ であったが、期待していたバルクの最高 $T_{\mathrm{c}}$ よりは低かった。これは MBE 成長した Ba122:P 薄膜 ${ }^{44)}$ でも報告されているように歪みの効果と考えられる。そし て、成長速度の最適化を行ったところ（Fig. 5(b)）、X 線回 折で評価した結晶性に違いは一切なかったが、成長速度を 遅くするに従って、磁場中 $J_{\mathrm{c}}$ の絶対值が増加し、その等方 性も増す傾向を見いだした。走査型電子顕微鏡観察の結果、 薄膜成長中に形成された $c$ 軸方向の欠陥が効果的な磁束ピ ニング中心として働くことを明らかにした。そして、4 K、 $9 \mathrm{~T}$ で $1 \mathrm{MA} / \mathrm{cm}^{2}$ を超える $J_{\mathrm{c}}$ を達成した。

この最適化した Ba122:P 薄膜成長条件を IBAD 金属テー プ基板上への線材薄膜成長へ適用したところ 45-47)、8 度と 面内配向度が悪いテープ基板においてでも $15 \mathrm{~T}$ で 0.1 $\mathrm{MA} / \mathrm{cm}^{2}$ と $\mathrm{NbTi}$ や $\mathrm{Nb}_{3} \mathrm{Sn}$ といった実用線材レベルの特性が 得られることも最近実証された ${ }^{46)}$ 。

\section{$3.5 J_{\mathrm{c}}$ 性能比較}

Fig. 6 にこれまでに我々のグループで作製した Ba122 薄 膜の磁場下での $J_{\mathrm{c}}$ 特性を示し、代表的な他の研究グループ

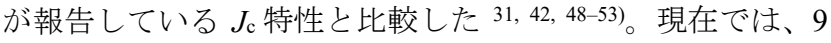
$\mathrm{T}$ の外部磁場下において $0.1 \mathrm{MA} / \mathrm{cm}^{2}$ を越える $J_{\mathrm{c}}$ が多く報告 されており、最近 Yuan ら ${ }^{53)}$ によって報告された $\mathrm{CaF}_{2}$ 単結 晶基板上の $\mathrm{Ba} 122: \mathrm{Co}$ 薄膜では、9 $\mathrm{T}$ 下で $1 \mathrm{MA} / \mathrm{cm}^{2}$ を大幅
に超えた。

\section{6 希土類添加 $\mathrm{BaFe}_{2} \mathrm{As}_{2}$ (Ba122:Re)}

2011 年、希土類添加した $\mathrm{CaFe}_{2} \mathrm{As}_{2}$ (Ca122:Re) 単結晶が $T_{\mathrm{c}} \approx 50 \mathrm{~K}$ と報告された ${ }^{54,55)}$ 。希土類不純物は $\mathrm{Ba}$ サイトを 置換することから、フェルミ面を構成する $\mathrm{Fe}$ サイトへの 直接ドープとなる Co と違い、間接ドープに成功したこと がその高い $T_{\mathrm{c}}$ につながっていると思われた。また、添加物 となる希土類金属は Co と同様、高融点・低蒸気圧である ことから、薄膜作製の際の添加物に適していると判断した。 我々が採用している Nd:YAG PLD 法では、アルカリ土類 122 型化合物の中で Ca122 相薄膜の合成だけは成功してい なかった ${ }^{30)}$ ため（MBE では Ca122 薄膜の合成に成功して いる ${ }^{56)}$ )、 、 Ca122 以外、すなわち、Ba122 および Sr122 相 への希土類ドーピングに挑戦した。どちらも一般的な固相 反応により得られるバルク体では報告のないドーピング手 法であるが、PLD の非平衡プロセスを利用することによっ て、希土類ドープ $\mathrm{Ba} 122: \operatorname{Re}(\operatorname{Re}=\mathrm{La}-\mathrm{Nd})^{57-59)}$ と $\mathrm{Sr} 122: \mathrm{La}$ 60)を、 $\mathrm{MgO}(001)$ と $\operatorname{LSAT}(001)$ 単結晶上にエピタキシャル薄 膜としてそれぞれ安定化させることに成功した。こうして 非平衡相の合成に成功し、超伝導転移を観察することはで きたが、その $T_{\mathrm{c}}$ は期待に反して、Co ドープの值とほぼ全 く同じで、Ca122:Re 単結晶で報告された $50 \mathrm{~K}$ 級の $T_{\mathrm{c}}$ を達 成することはできなかった（Fig. 7）。この研究で明らかに なったことは、Ba122 は直接・間接「電子」ドープでその

(a)
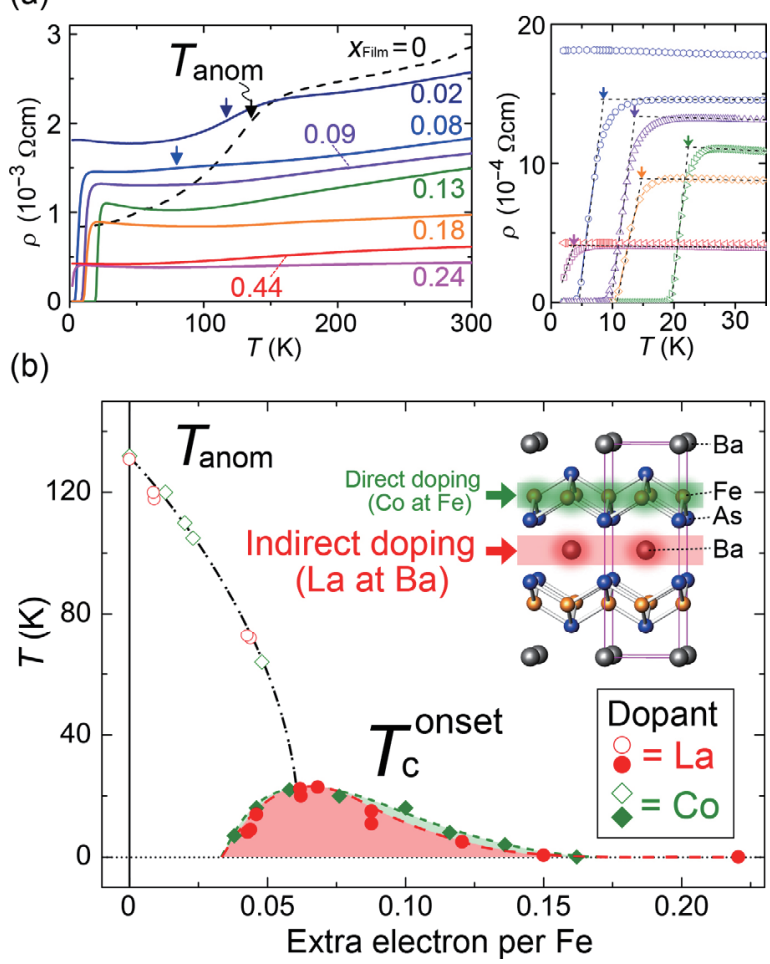

Fig. 7 (a) Temperature dependence of resistivity of indirectly La-doped Ba122 epitaxial films. (b) The electronic phase diagram of Ba122:La. That of directly doped Ba122:Co is shown for comparison. ${ }^{57)}$ 
(a)

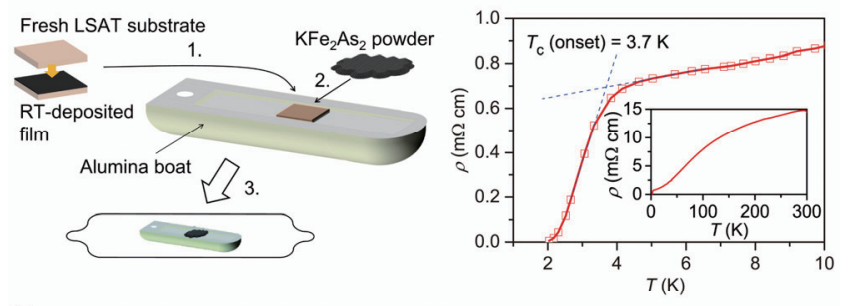

(b)

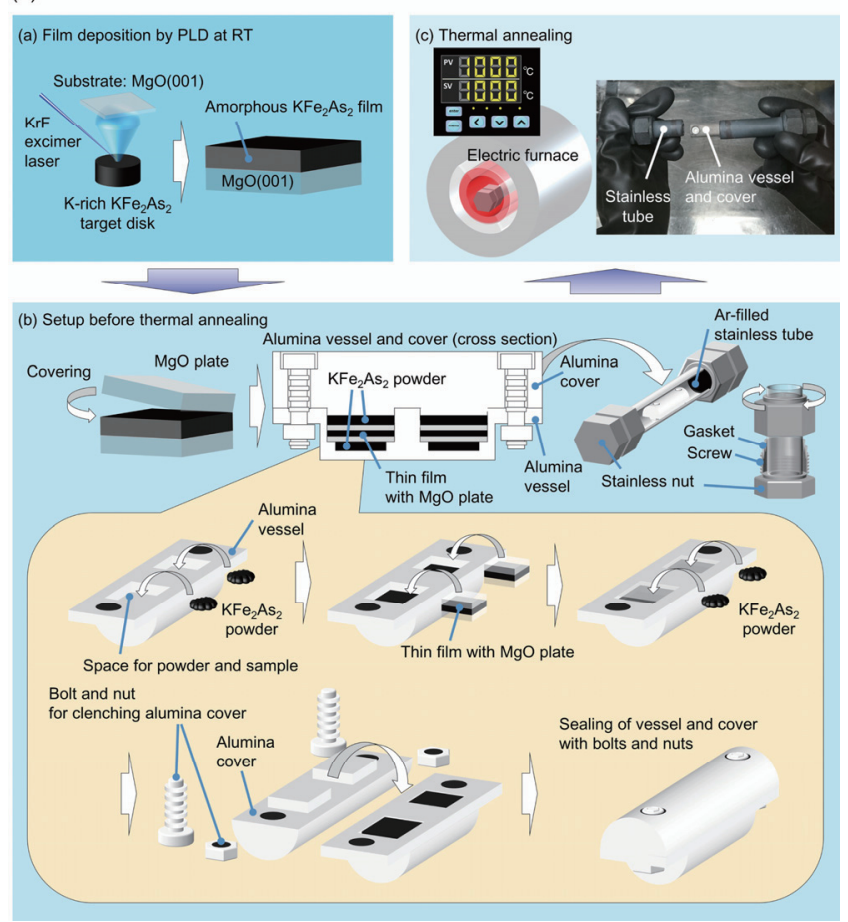

Fig. 8 Solid-phase epitaxy technique for K122 thin-film growth. (a) Set-up before thermal annealing and $\rho-T$ of the $c$-axis-oriented K122 film. ${ }^{62)}$ (b) The improved solid-phase epitaxy technique for K122 epitaxial growth. ${ }^{63)}$

$T_{\mathrm{c}}$ に差が無いという、鉄系超伝導体は銅酸化物と違って、 直接ドープが有効であると言われていたことを別の手法で 示した形となった。

\section{3. $7 \mathrm{KFe}_{2} \mathrm{As}_{2} \quad(\mathrm{~K} 122)$}

122 型の鉄系超伝導体 $\mathrm{K} 122$ の $T_{\mathrm{c}}$ は $3 \mathrm{~K}$ と低く、かつア ルカリ金属であるカリウム（K）を主成分とするため、大 気中で不安定であることから、将来応用へは向いていない。 ところが、2012 年に Pandey ら ${ }^{61)}$ によって、Fe 3d 軌道の 強いスピン一軌道相互作用に起因して、スピンホール伝導 度が Pt 並みに大きいことが理論予測された。スピンホール 伝導度の実験的な立証には、通常の単結晶ではなく、まず はナノメートルオーダーの薄膜試料とその微細加工が必要 不可欠となるため、我々はこの K122 のエピタキシャル薄 膜の作製を試みた ${ }^{62)}$ 。

着手前から予想していたが、カリウムの膜中への取り込 みが非常に難しかった。そして、Fig. 8(a)に示したように 室温で PLD 成長させた LSAT(001)基板上の非晶質 K122 膜
をアルミナボート中にセットアップし、昇温して結晶化す る際に K の蒸気圧を補償するため、試料周りを大量の多結 晶 $\mathrm{KFe}_{2} \mathrm{As}_{2}$ 粉末で覆って、真空ガラス封管するという、固 相エピタキシャル成長法を開発することによって、結晶化 のための熱処理の際に膜中の $\mathrm{K}$ 成分の蒸発を防ぐことがで き、強く $c$ 軸配向した K122 薄膜の作製に成功し、バルク 試料と同等の $T_{\mathrm{c}}$ も確認できた。そしてさらに結晶性を改善 するために、特製のアルミナボートを設計し（Fig. 8(b)）、 試料周りの気密性を大幅に改善することによって、Fig. 8(a) に示した固相エピタキシャル成長法では最高で $700^{\circ} \mathrm{C}$ まで しか上げられなかったが、Fig. 8(b)ではそれを $1000^{\circ} \mathrm{C}$ にま で上昇させることができ、面内も配向した K122 エピタキ シャル薄膜の合成に成功した ${ }^{63)}$ 。これからの課題は、いか にしてこの大気中で不安定な試料をナノメートルオーダー まで微細加工するか、その手法開発である。

\section{FeSe 薄膜を使った電気二重層トランジスタ}

2012 年、MBE 法で 1 単位格子分の厚さの 11 型 FeSe 超 薄膜を $\mathrm{SrTiO}_{3}$ 単結晶上に成長させると、その $T_{\mathrm{c}}$ が $50 \mathrm{~K}$ を 遙かに超えることが報告された ${ }^{64)}$ 。その FeSe「超」薄膜 の研究はものすごいスピードで発展しており 65,66 、現在そ

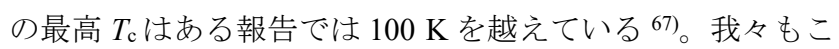
の高い $T_{\mathrm{c}}$ に即座に興味を持ち、MBE 法による $\mathrm{FeSe}$ 薄膜の 合成に着手した。しかしながら、残念ながら我々のグルー プでは、RHEED 振動を確認しながらの 1 単位格子分の厚 さ制御された試料の合成に未だ成功していない。

そういった中で我々は、数 $10 \mathrm{~nm}$ オーダー厚の FeSe エ ピタキシャル薄膜の特異性に目を付けた。FeSe はバルク体 では $T_{\mathrm{c}}=8 \mathrm{~K}$ の超伝導体であるが、そのオーダーの厚さに なると、本来の金属的な伝導特性から絶縁体的（温度低下 に伴って抵抗率が上昇する）に変化することが既に報告さ れており、我々もそれをすぐに再現した。そして、その絶
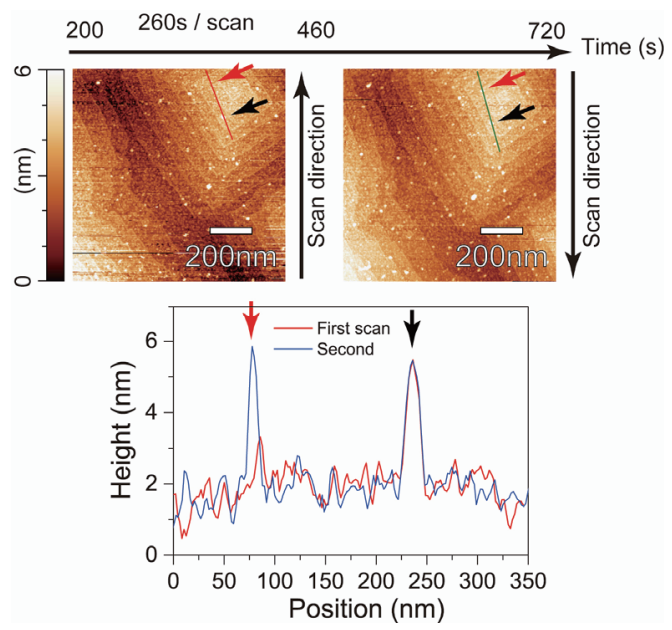

Fig. 9 Surface morphology of an FeSe epitaxial film grown by MBE and the cross-section profile along each line. 
縁体的な伝導特性から、バルクでは金属的でマルチバンド の電子構造が、面内歪み等の影響により絶縁体的に変化し ていると期待した。それはあたかも強い電子相関を有する 絶縁体とみなせることから、銅酸化物超伝導体のように思 えた。そこで、強相関モット絶縁体の磁気秩序を高濃度 キャリアドープで崩して高 $T_{\mathrm{c}}$ につなげる、という銅酸化物 に類似したシナリオを適用することにした。類似したアプ ローチで 122 型（母相は 245 型）の絶縁体 $\mathrm{TlFe}_{1.6} \mathrm{Se}_{2}$ の電 気二重層トランジスタ（EDLT）を作製し高濃度キャリア ドープによる絶縁体一金属転移に成功していたことから 68)、 その作製法をこの MBE 成長した FeSe 薄膜に適用した。

しかしながら、その FeSe の EDLT 作製過程において、 一つ大きな問題に直面した。作製した FeSe 薄膜の表面を 原子間力顕微鏡で観察した際に、小さなパーティクル状の 異物がいつも必ず析出しており、それがたったもう一回ス キャンする間に増殖するのを確認した（Fig. 9）。従って、 FeSe 薄膜の表面は大気中の水分もしくは酸素などに非常に 敏感で取り扱いにくいことが明らかとなった。実際に表面 劣化した試料を使って EDLT を作製してもゲート電圧印加 下においてチャネル抵抗は全く変調しなかった。

そこで、FeSe 薄膜試料を一切大気に触れさせることなく、 真空もしくは Ar 雾囲気下です心゙て搬送し、デバイス作製 が可能な全 in-situ プロセスを開発した（Fig. 10）。

Fig. 11 にデバイス構造と、その EDLT 特性をまとめた ${ }^{69) 。 ~}$

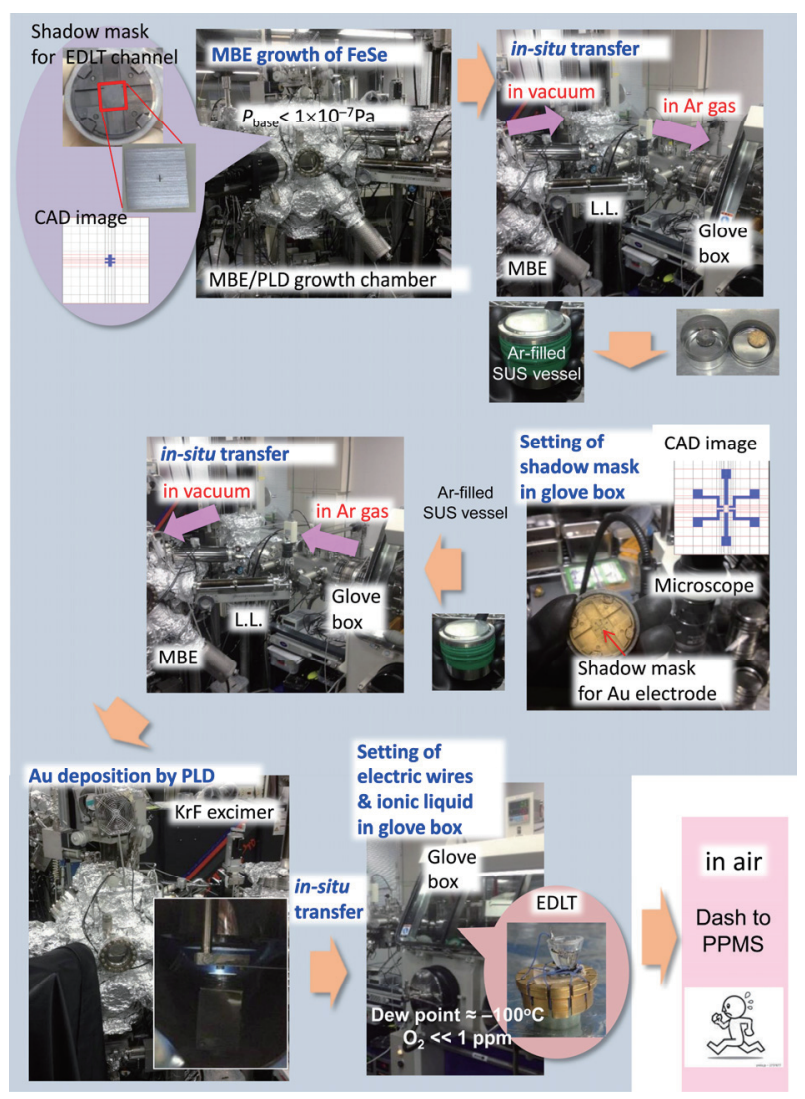

Fig. 10 All in-situ process for fabrication of FeSe EDLT.
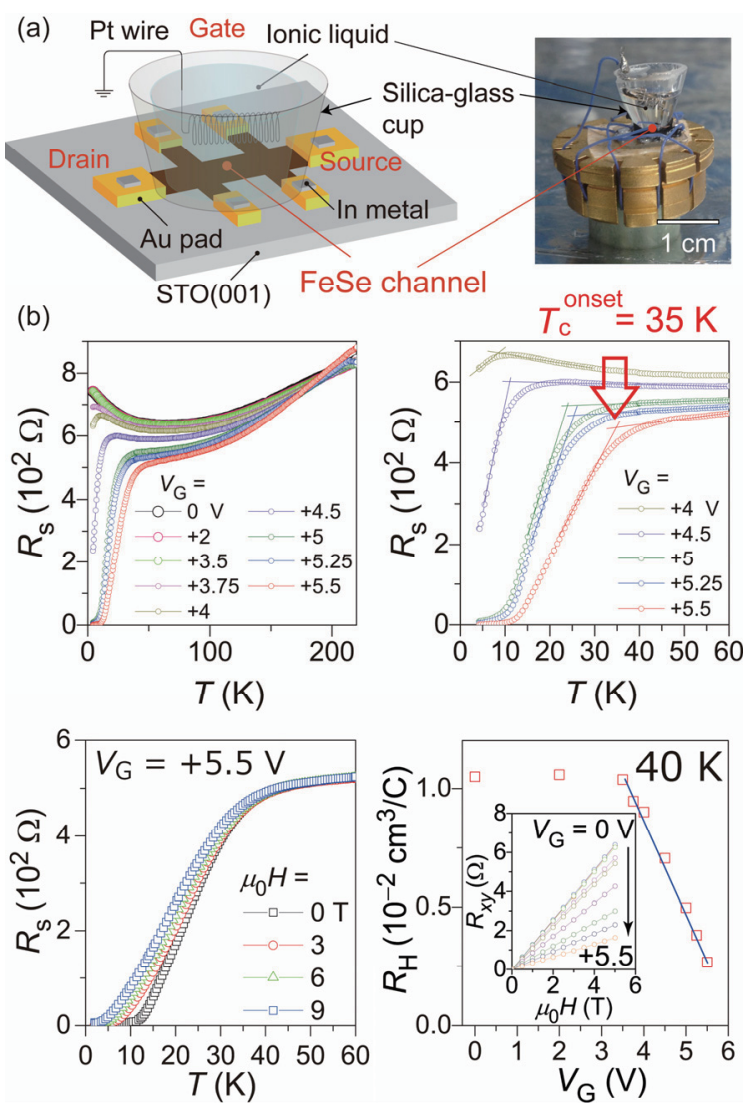

Fig. 11 EDLT using FeSe films grown by MBE. (a) Device structure. (b) Transport properties under gate voltages $\left.\left(V_{\mathrm{G}}\right) .^{69}\right)$

ゲート電圧 $\left(V_{\mathrm{G}}\right) \quad 0 \mathrm{~V}$ の場合は、温度が下がるに従って シート抵抗值 $\left(R_{\mathrm{S}}\right)$ が上昇する絶縁体的な挙動を示したが、 $V_{\mathrm{G}}=+4 \mathrm{~V}$ の際に $T_{\mathrm{c}}{ }^{\text {onset }}=8.6 \mathrm{~K}$ を観察し、その後は $V_{\mathrm{G}}$ の増 加に伴って $T_{\mathrm{c}}$ onset も上昇した。そして、 $V_{\mathrm{G}}=+5.5 \mathrm{~V}$ の際に 最大の $T_{\mathrm{c}}{ }^{\text {onset }}=35 \mathrm{~K}$ を観察した。外部磁場依存性から上部 臨界磁場の非常に高い超伝導であることも確認した。 $V_{\mathrm{G}}$ 印 加下の Hall 効果測定を行ったところ、ホール係数 $R_{\mathrm{H}}$ の低 下を確認した。粗く見積もったシートキャリア濃度は $10^{15}$ $\mathrm{cm}^{-2}$ に達しており、EDLT による高濃度キャリアドープが バルクより 4 倍以上高い $T_{\mathrm{c}}$ の起源であると結論づけた。た だ、詳細はいまだ不明である。また、最近この高い $T_{\mathrm{c}}$ を得 るためには、MBEの条件をかなり綿密に最適化しなければ ならないことも報告した 70)。研究のアプローチは異なるが、 このような高い $T_{\mathrm{c}}$ は FeSe を使った EDLT で多く報告され はじめており 71-74)、起源の特定が今後の新物質発見の種に なることを期待している。

\section{5. おわりに}

2008 年から我々の研究グループで取り組んできた鉄系超 伝導体「薄膜」の研究を物質群ごとに分類して紹介した。 鉄系超伝導体は、その発見から来年でちょうど 10 年と大 きな節目を迎える。将来の応用を目指した研究分野では、 ジョセフソン接合や SQUID として有望な結果はまだ見受 
けられていないように思われるが、物質本来の特性を活用 した線材等への応用を目指した研究は順調に進んできてい るように感じている。そして、鉄系超伝導体薄膜研究の次 の大きなステップは、有効な磁束ピニング中心の発見と、 線材の長尺化のデモンストレーションと感じる。

本研究は、文部科学省元素戦略プロジェクト<研究拠点 形成型 $>$ 支援により、東京工業大学 科学技術創成研究 院 フロンティア材料研究所の神谷利夫 教授、片瀬貴義 准教授、佐藤 光 博士（現：GE ヘルスケアジャパン技術 本部)、博士課程 2 年半沢幸太 氏を含む大学院生、ならび に国際超電導産業技術研究センター（現：超電導センシン グ技術研究組合）の田辺圭一 所長の研究グループとの共 同で行われた。一部は、新学術領域研究（No. 25106007）、 科研費・基盤 (A)（No. 17H01318）、東京工業大学「東工大 の星」支援 (Support for Tokyotech Advanced Research, STAR) からの研究助成を受けた。

\section{参 考 文 献}

1) For a review, H. Hiramatsu, H. Kamioka, K. Ueda, H. Ohta, T. Kamiya, M. Hirano and H. Hosono: "Opto-electronic properties and light-emitting device application of widegap layered oxychalcogenides: $\mathrm{LaCuOCh}(\mathrm{Ch}=$ chalcogen $)$ and $\mathrm{La}_{2} \mathrm{CdO}_{2} \mathrm{Se}_{2}$," phys. stat. sol. (a) 203 (2006) 2800.

2) Y. Kamihara, H. Hiramatsu, M. Hirano, R. Kawamura, H. Yanagi, T. Kamiya and H. Hosono: "Iron-based layered superconductor: LaOFeP,”J. Am. Chem. Soc. 128 (2006) 10012.

3) T. Watanabe, H. Yanagi, T. Kamiya, Y. Kamihara, H. Hiramatsu, M. Hirano and H. Hosono: "Nickel-based oxyphosphide superconductor with a layered crystal structure, LaNiOP," Inorg. Chem. 46 (2007) 7719.

4) Y. Kamihara, T. Watanabe, M. Hirano and H. Hosono: "Iron-based layered superconductor $\mathrm{La}\left[\mathrm{O}_{1-x} \mathrm{~F}_{x}\right] \mathrm{FeAs}(x=0.05-0.12)$ with $T_{\mathrm{c}}=$ 26 K," J. Am. Chem. Soc. 130 (2008) 3296.

5) 総説：細野秀雄, 松石 聡, 野村尚利, 平松秀典：「鉄系超伝 導物質」, 日本物理学会誌 64 (2009) 807.

6) 総説：前田京剛, 今井良宗, 高橋英幸 :「鉄系超伝導体研究の 現状」, 固体物理 46 (2011) 453 .

7) For a review, H. Hosono and K. Kuroki: "Iron-based superconductors: Current status of materials and pairing mechanism," Physica C 514 (2015) 399.

8) H. Hiramatsu, T. Katase, T. Kamiya, M. Hirano and H. Hosono: "Heteroepitaxial growth and optoelectronic properties of layered iron oxyarsenide, LaFeAsO,” Appl. Phys. Lett. 93 (2008) 162504.

9) H. Hiramatsu, T. Katase, T. Kamiya, M. Hirano and H. Hosono: "Superconductivity in epitaxial thin films of Co-doped $\mathrm{SrFe}_{2} \mathrm{As}_{2}$ with bilayered FeAs structures and their magnetic anisotropy," Appl. Phys. Express 1 (2008) 101702.

10) T. Katase, H. Hiramatsu, H. Yanagi, T. Kamiya, M. Hirano and H. Hosono: "Atomically-flat, chemically-stable, superconducting epitaxial thin film of iron-based superconductor, cobalt-doped $\mathrm{BaFe}_{2} \mathrm{As}_{2}$," Solid State Commun. 149 (2009) 2121.
11) For a review, H. Hiramatsu, T. Kamiya, M. Hirano and H. Hosono: "Heteroepitaxial film growth of layered compounds with the $\mathrm{ZrCuSiAs}$-type and $\mathrm{ThCr}_{2} \mathrm{Si}_{2}$-type structures: from $\mathrm{Cu}$-based semiconductors to Fe-based superconductors," Physica C 469 (2009) 657.

12) For a review, Q. Li, W. Si and I. K. Dimitrov: "Films of iron chalcogenide superconductors,” Rep. Prog. Phys. 74 (2011) 124510.

13) For a review, P. Seidel: "Josephson effects in iron based superconductors," Supercond. Sci. Technol. 24 (2011) 043001.

14) For a review, H. Hiramatsu, T. Katase, T. Kamiya, and H. Hosono: "Thin film growth and device fabrication of iron-based superconductors” J. Phys. Soc. Jpn. 81 (2012) 011011.

15) For a review, K. Tanabe and H. Hosono: "Frontiers of research on iron-based superconductors toward their application” Jpn. J. Appl. Phys. 51 (2012) 010005.

16) For a review, P. Mele: "Superconducting properties of iron chalcogenide thin films," Sci. Technol. Adv. Mater. 13 (2012) 054301 .

17) For a review, S. Haindl, M. Kidszun, S. Oswald, C. Hess, B. Büchner, S. Kölling, L. Wilde, T. Thersleff, V. V. Yurchenko, M. Jourdan, H. Hiramatsu and H. Hosono: "Thin film growth of Febased superconductors: from fundamental properties to functional devices. A comparative review," Rep. Prog. Phys. 77 (2014) 046502.

18) For a review, H. Hosono, A. Yamamoto, H. Hiramatsu and Y. Ma: "Recent advances in iron-based superconductors toward applications," Mater. Today (published online), DOI: 10.1016/j.mattod.2017.09.006

19) T. Kawaguchi, H. Uemura, T. Ohno, R. Watanabe, M. Tabuchi, T. Ujihara, K. Takenaka, Y. Takeda and H. Ikuta: "Epitaxial Growth of NdFeAsO Thin Films by Molecular Beam Epitaxy," Appl. Phys. Express 2 (2009) 093002.

20) T. Kawaguchi, H. Uemura, T. Ohno, M. Tabuchi, T. Ujihara, K. Takenaka, Y. Takeda and H. Ikuta: "In situ growth of superconducting $\operatorname{NdFeAs}(\mathrm{O}, \mathrm{F})$ thin films by molecular beam epitaxy," Appl. Phys. Lett. 97 (2010) 042509.

21) T. Kawaguchi, H. Uemura, T. Ohno, M. Tabuchi, T. Ujihara, Y. Takeda and H. Ikuta: "Molecular beam epitaxy growth of superconducting $\operatorname{NdFeAs}(\mathrm{O}, \mathrm{F})$ thin films using a F-getter and a novel F-doping method," Appl. Phys. Express 4 (2011) 083102.

22) S. Ueda, S. Takeda, S. Takano, A. Yamamoto and M. Naito: "High$T_{\mathrm{c}}$ and high- $J_{\mathrm{c}} \operatorname{SmFeAs}(\mathrm{O}, \mathrm{F})$ films on fluoride substrates grown by molecular beam epitaxy," Appl. Phys. Lett. 99 (2011) 232505.

23) S. Ueda, S. Takeda, S. Takano, and M. Naito: "As-grown superconducting $\operatorname{SmFeAs}(\mathrm{O}, \mathrm{F})$ thin films by molecular beam epitaxy," Appl. Phys. Express 5 (2012) 053101.

24) H. Sugawara, T. Tsuneki, D. Watanabe, A. Yamamoto, M. Sakoda and M. Naito: "One-step growth of $\operatorname{SmFeAs}(\mathrm{O}, \mathrm{F})$ films by molecular beam epitaxy using $\mathrm{FeF}_{2}$ as a fluorine source," Supercond. Sci. Technol. 28 (2015) 015005.

25) S. Haindl, K. Hanzawa, H. Sato, H. Hiramatsu and H. Hosono: "In-situ growth of superconducting $\mathrm{SmO}_{1-x} \mathrm{~F}_{x} \mathrm{FeAs}$ thin films by pulsed laser deposition," Sci. Rep. 6 (2016) 35797.

26) S. Haindl, S. Molatta, H. Hiramatsu and H. Hosono: "Recent progress in pulsed laser deposition of iron based superconductors," J. Phys. D: Appl. Phys. 49 (2016) 345301. 
27) S. Haindl, H. Kinjo, K. Hanzawa, H. Hiramatsu and H. Hosono: "Pulsed laser deposition of $\mathrm{SmFeAsO}_{1-\delta}$ on $\mathrm{MgO}(100)$ substrates," Appl. Surf. Sci. (published online), DOI: 10.1016/j.apsusc.2017.08.061

28) H. Hiramatsu, T. Katase, T. Kamiya, M. Hirano and H. Hosono: "Water-induced superconductivity in $\mathrm{SrFe}_{2} \mathrm{As}_{2}$," Phys. Rev. B 80 (2009) 052501.

29) T. Katase, H. Hiramatsu, T. Kamiya and H. Hosono: "High critical current density $4 \mathrm{MA} / \mathrm{cm}^{2}$ in Co-doped $\mathrm{BaFe}_{2} \mathrm{As}_{2}$ epitaxial films grown on $(\mathrm{La}, \mathrm{Sr})(\mathrm{Al}, \mathrm{Ta}) \mathrm{O}_{3}$ substrates without buffer layers," Appl. Phys. Express 3 (2010) 063101

30) T. Katase, H. Hiramatsu, T. Kamiya and H. Hosono: "Thin film growth by pulsed laser deposition and properties of 122-type ironbased superconductor $\mathrm{AE}\left(\mathrm{Fe}_{1-x} \mathrm{Co}_{x}\right)_{2} \mathrm{As}_{2}$ ( $\mathrm{AE}=$ alkaline earth)," Supercond. Sci. Technol. 25 (2012) 084015.

31) H. Hiramatsu, T. Katase, Y. Ishimaru, A. Tsukamoto, T. Kamiya, K. Tanabe and H. Hosono: "Microstructure and transport properties of [001]-tilt bicrystal grain boundaries in iron pnictide superconductor, cobalt-doped $\mathrm{BaFe}_{2} \mathrm{As}_{2}$," Mater. Sci. Eng. B 177 (2012) 515

32) B. Maiorov, T. Katase, S.A. Baily, H. Hiramatsu, T.G. Holesinger, H. Hosono and L. Civale: "Liquid vortex phase and strong $c$-axis pinning in low anisotropy $\mathrm{BaCo}_{x} \mathrm{Fe}_{2-x} \mathrm{As}_{2}$ pnictide films," Supercond. Sci. Technol. 24 (2011) 055007.

33) H. Sato, T. Katase, W.N. Kang, H. Hiramatsu, T. Kamiya and H. Hosono: "Anomalous scaling behavior in a mixed-state Hall effect of a cobalt-doped $\mathrm{BaFe}_{2} \mathrm{As}_{2}$ epitaxial film with a high critical current density over 1 MA/cm²," Phys. Rev. B 87 (2013) 064504.

34) S. Lee, J. Jiang, Y. Zhang, C.W. Bark, J.D.Weiss, C. Tarantini, C.T. Nelson, H.W. Jang, C.M. Folkman, S.H. Baek, A. Polyanskii, D. Abraimov, A. Yamamoto, J.W. Park, X.Q. Pan, E.E. Hellstrom, D.C. Larbalestier and C.B. Eom: "Template engineering of Codoped $\mathrm{BaFe}_{2} \mathrm{As}_{2}$ single-crystal thin films," Nat. Mater. 9 (2010) 397.

35) T. Thersleff, K. Iida, S. Haindl, M. Kidszun, D. Pohl, A. Hartmann, F. Kurth, J. Hänisch, R. Hühne, B. Rellinghaus, L. Schultz and B. Holzapfel: "Coherent interfacial bonding on the FeAs tetrahedron in $\mathrm{Fe} / \mathrm{Ba}\left(\mathrm{Fe}_{1-x} \mathrm{Co}_{x}\right)_{2} \mathrm{As}_{2}$ bilayers," Appl. Phys. Lett. 97 (2010) 022506.

36) H. Hiramatsu, H. Sato, T. Katase, T. Kamiya and H. Hosono: "Critical factor for epitaxial growth of cobalt-doped $\mathrm{BaFe}_{2} \mathrm{As}_{2}$ films by pulsed laser deposition,” Appl. Phys. Lett. 104 (2014) 172602.

37) T. Katase, Y. Ishimaru, A. Tsukamoto, H. Hiramatsu, T. Kamiya, K Tanabe and H. Hosono: "Josephson junction in cobalt-doped $\mathrm{BaFe}_{2} \mathrm{As}_{2}$ epitaxial thin films on $(\mathrm{La}, \mathrm{Sr})(\mathrm{Al}, \mathrm{Ta}) \mathrm{O}_{3}$ bicrystal substrates," Appl. Phys. Lett. 96 (2010) 142507.

38) T. Katase, Y. Ishimaru, A. Tsukamoto, H. Hiramatsu, T. Kamiya, K Tanabe and H. Hosono: "Advantageous grain boundaries in iron pnictide superconductors," Nat. Commun. 2 (2011) 409.

39) T. Katase, Y. Ishimaru, A. Tsukamoto, H. Hiramatsu, T. Kamiya, K. Tanabe and H. Hosono: "DC superconducting quantum interference devices fabricated using bicrystal grain boundary junctions in Co-doped $\mathrm{BaFe}_{2} \mathrm{As}_{2}$ epitaxial films," Supercond. Sci. Technol. 23 (2010) 082001.

40) W. Si, C. Zhang, X. Shi, T. Ozaki, J. Jaroszynski and Q. Li: “Grain boundary junctions of $\mathrm{FeSe}_{0.5} \mathrm{Te}_{0.5}$ thin films on $\mathrm{SrTiO}_{3}$ bi-crystal substrates," Appl. Phys. Lett. 106 (2015) 032602.
41) T. Katase, H. Hiramatsu, V. Matias, C. Sheehan, Y. Ishimaru, T. Kamiya, K. Tanabe and H. Hosono: "Biaxially textured cobaltdoped $\mathrm{BaFe}_{2} \mathrm{As}_{2}$ films with high critical current density over 1 $\mathrm{MA} / \mathrm{cm}^{2}$ on $\mathrm{MgO}$-buffered metal-tape flexible substrates," Appl. Phys. Lett. 98 (2011) 242510.

42) H. Sato, H. Hiramatsu, T. Kamiya and H. Hosono: "High criticalcurrent density with less anisotropy in $\mathrm{BaFe}_{2}(\mathrm{As}, \mathrm{P})_{2}$ epitaxial thin films: Effect of intentionally grown $c$-axis vortex-pinning centers," Appl. Phys. Lett. 104 (2014) 182603.

43) H. Sato, H. Hiramatsu, T. Kamiya and H. Hosono: "Vortex pinning property of phosphorous-doped $\mathrm{BaFe}_{2} \mathrm{As}_{2}$ epitaxial films: comparison between $(\mathrm{La}, \mathrm{Sr})(\mathrm{Al}, \mathrm{Ta}) \mathrm{O}_{3}$ and $\mathrm{MgO}$ substrates," IEEE Trans. Appl. Supercond. 25 (2015)7500305.

44) T. Kawaguchi, A. Sakagami, Y. Mori, M. Tabuchi, T. Ujihara, Y. Takeda and H. Ikuta: "The strain effect on the superconducting properties of $\mathrm{BaFe}_{2}(\mathrm{As}, \mathrm{P})_{2}$ thin films grown by molecular beam epitaxy," Supercond. Sci. Technol. 27 (2014) 065005.

45) H. Sato, H. Hiramatsu, T. Kamiya and H. Hosono: "Enhanced critical-current in P-doped $\mathrm{BaFe}_{2} \mathrm{As}_{2}$ thin films on metal substrates arising from poorly aligned grain boundaries," Sci. Rep. 6 (2016) 36828.

46) K. Iida, H. Sato, C. Tarantini, J. Hänisch, J. Jaroszynski, H. Hiramatsu, B. Holzapfel and H. Hosono: "High-field transport properties of a P-doped $\mathrm{BaFe}_{2} \mathrm{As}_{2}$ film on technical substrate," Sci. Rep. 7 (2017) 39951.

47) H. Hiramatsu, H. Sato, T. Kamiya and H. Hosono: " $\mathrm{BaFe}_{2}\left(\mathrm{As}_{1-x} \mathrm{P}_{x}\right)_{2} \quad(x=0.22-0.42)$ thin films grown on practical metal-tape substrates and their critical current densitie,s" Supercond. Sci. Technol. 30 (2017) 044003.

48) K. Iida, S. Haindl, T. Thersleff, J. Hänisch, F. Kurth, M. Kidszun, R. Hühne, I. Mönch, L. Schultz, B. Holzapfel and R. Heller: "Influence of Fe buffer thickness on the crystalline quality and the transport properties of $\mathrm{Fe} / \mathrm{Ba}\left(\mathrm{Fe}_{1-x} \mathrm{Co}_{x}\right)_{2} \mathrm{As}_{2}$ bilayers," Appl. Phys. Lett. 97 (2010) 172507.

49) M. Miura, B. Maiorov, T. Kato, T. Shimode, K. Wada, S. Adachi and K. Tanabe: "Strongly enhanced flux pinning in one-step deposition of $\mathrm{BaFe}_{2}\left(\mathrm{As}_{0.66} \mathrm{P}_{0.33}\right)_{2}$ superconductor films with uniformly dispersed $\mathrm{BaZrO}_{3}$ nanoparticles," Nat. Commun. 4 (2013) 2499.

50) S. Lee, C. Tarantini, P. Gao, J. Jiang, J.D.Weiss, F. Kametani, C.M. Folkman, Y. Zhang, X.Q. Pan, E.E. Hellstrom, D.C. Larbalestier and C.B. Eom: "Artificially engineered superlattices of pnictide superconductors," Nat. Mater. 12 (2013) 392.

51) C. Tarantini, F. Kametani, S. Lee, J. Jiang, J.D. Weiss, J. Jaroszynski, E.E. Hellstrom, C.B. Eom and D.C. Larbalestier: "Development of very high $J_{\mathrm{c}}$ in $\mathrm{Ba}\left(\mathrm{Fe}_{1-x} \mathrm{Co}_{x}\right)_{2} \mathrm{As}_{2}$ thin films grown on $\mathrm{CaF}_{2}$," Sci. Rep. 4 (2014) 7305.

52) F. Kurth, C. Tarantini, V. Grinenko, J. Hänisch, J. Jaroszynski, E. Reich, Y. Mori, A. Sakagami, T. Kawaguchi, J. Engelmann, L. Schultz, B. Holzapfel, H. Ikuta, R. Hühne and K. Iida: "Unusually high critical current of clean $\mathrm{P}$-doped $\mathrm{BaFe}_{2} \mathrm{As}_{2}$ single crystalline thin film," Appl. Phys. Lett. 106 (2015) 072602.

53) P. Yuan, Z. Xu, D. Wang, M. Zhang, J. Li and Y. Ma: "Vortex pinning properties in Co-doped $\mathrm{BaFe}_{2} \mathrm{As}_{2}$ thin films with a high critical current density over $2 \mathrm{MAcm}^{-2}$ at 9T," Supercond. Sci. Technol. 30 (2017) 025001. 
54) B. Lv, L. Deng, M. Gooch, F. Wei, Y. Sun, J. K. Meen, Y.-Y. Xue, B. Lorenz and C.-W. Chu: "Unusual superconducting state at $49 \mathrm{~K}$ in electron-doped $\mathrm{CaFe}_{2} \mathrm{As}_{2}$ at ambient pressure," Proc. Natl. Acad. Sci. USA 108 (2011) 15705.

55) S.R. Saha, N.P. Butch, T. Drye, J. Magill, S. Ziemak, K. Kirshenbaum, P.Y. Zavalij, J.W. Lynn and J. Paglione: "Structural collapse and superconductivity in rare-earth-doped $\mathrm{CaFe}_{2} \mathrm{As}_{2}$," Phys. Rev. B 85 (2012) 024525.

56) T. Hatano, T. Kawaguchi, R. Fujimoto, I. Nakamura, Y. Mori, S. Harada, T. Ujihara and H. Ikuta: "Thin film growth of $\mathrm{CaFe}_{2} \mathrm{As}_{2}$ by molecular beam epitaxy," Supercond. Sci. Technol. 29 (2016) 015013.

57) T. Katase, S. Iimura, H. Hiramatsu, T. Kamiya and H. Hosono: "Identical effects of indirect and direct electron doping of superconducting $\mathrm{BaFe}_{2} \mathrm{As}_{2}$ thin films," Phys. Rev. B 85 (2012) $140516(\mathrm{R})$.

58) T. Katase, H. Hiramatsu, T. Kamiya and H. Hosono: "Magnetic scattering and electron pair breaking by rare-earth-ion substitution in $\mathrm{BaFe}_{2} \mathrm{As}_{2}$ epitaxial films," New J. Phys. 15 (2013) 073019.

59) T. Katase, H. Sato, H. Hiramatsu, T. Kamiya and H. Hosono: "Unusual pressure effects on the superconductivity of indirectly electron-doped $\left(\mathrm{Ba}_{1-x} \mathrm{La}_{x}\right) \mathrm{Fe}_{2} \mathrm{As}_{2}$ epitaxial films," Phys. Rev. B 88 (2013) 140503(R).

60) H. Hiramatsu, T. Katase, T. Kamiya and H. Hosono: "Superconducting properties and phase diagram of indirectly electron-doped $\left(\mathrm{Sr}_{1-x} \mathrm{La}_{x}\right) \mathrm{Fe}_{2} \mathrm{As}_{2}$ epitaxial films grown by pulsed laser deposition," IEEE Trans. Appl. Supercond. 23 (2013) 7300405

61) S. Pandey, H. Kontani, D. S. Hirashima, R. Arita and H. Aoki: "Spin Hall effect in iron-based superconductors: a Dirac-point effect,” Phys. Rev. B 86 (2012) 060507(R).

62) H. Hiramatsu, S. Matsuda, H. Sato, T. Kamiya and H. Hosono: "Growth of $c$-axis-oriented superconducting $\mathrm{KFe}_{2} \mathrm{As}_{2}$ thin films," ACS Appl. Mater. Interfaces 6 (2014) 14293.

63) T. Hatakeyama, H. Sato, H. Hiramatsu, T. Kamiya and H. Hosono: "Novel solid-phase epitaxy for multi-component materials with extremely high vapor pressure elements: an application to $\mathrm{KFe}_{2} \mathrm{As}_{2}$," Appl. Phys. Express 9 (2016) 055505.

64) Q.-Y. Wang, et al.: "Interface-induced high-temperature superconductivity in single unit-cell FeSe films on $\mathrm{SrTiO}_{3}$," Chin. Phys. Lett. 29 (2012) 037402.

$65)$ S. He, et al.: "Phase diagram and electronic indication of hightemperature superconductivity at $65 \mathrm{~K}$ in single-layer FeSe films," Nat. Mater. 12 (2013) 605.

66) For a review, Z. Wang, C. Liu, Y. Liu and J. Wang: "Hightemperature superconductivity in one-unit-cell FeSe films," J. Phys.: Condens. Matter 29 (2017) 153001.
67) J.-F. Ge, et al.: "Superconductivity above $100 \mathrm{~K}$ in single-layer FeSe films on doped $\mathrm{SrTiO}_{3}$," Nat. Mater. 14 (2015) 285.

68) T. Katase, H. Hiramatsu, T. Kamiya and H. Hosono: "Electric double-layer transistor using layered iron selenide Mott insulator $\mathrm{TlFe}_{1.6} \mathrm{Se}_{2}$," Proc. Natl. Acad. Sci. USA 111 (2014) 3979.

69) K. Hanzawa, H. Sato, H. Hiramatsu, T. Kamiya and H. Hosono: "Electric field-induced superconducting transition of insulating FeSe thin film at 35 K," Proc. Natl. Acad. Sci. USA 113 (2016) 3986.

70) K. Hanzawa, H. Sato, H. Hiramatsu, T. Kamiya and H. Hosono: "Key factors for insulator-superconductor transition in FeSe thin films by electric field," IEEE Trans. Appl. Supercond. 27 (2017) 7500405.

71) J. Shiogai, Y. Ito, T. Mitsuhashi, T. Nojima and A. Tsukazaki: "Electric-field-induced superconductivity in electrochemically etched ultrathin FeSe films on $\mathrm{SrTiO}_{3}$ and $\mathrm{MgO}$," Nat. Phys. 12 (2016) 42.

72) B. Lei, J.H. Cui, Z.J. Xiang, C. Shang, N.Z. Wang, G.J. Ye, X.G. Luo, T. Wu, Z. Sun and X.H. Chen: "Evolution of HighTemperature Superconductivity from a Low- $T_{\mathrm{c}}$ Phase Tuned by Carrier Concentration in FeSe Thin Flakes," Phys. Rev. Lett. 116 (2016) 077002.

73) W.-K. Wang, et al.: "The $45 \mathrm{~K}$ Onset Superconductivity and the Suppression of the Nematic Order in FeSe by Electrolyte Gating," Chin. Phys. Lett. 33 (2016) 057401.

74) J. Shiogai, T. Miyakawa, Y. Ito, T. Nojima and A. Tsukazaki: "Unified trend of superconducting transition temperature versus Hall coefficient for ultrathin FeSe films prepared on different oxide substrates," Phys. Rev. B 95 (2017) 115101.

平 松 秀 典 1973 年 9 月生。1996 年名古屋大学工学部応 用化学および物質化学科卒業。1998 年同大学院工学研究科博士 前期課程（物質化学専攻）修了。1998 年松下電器産業 (株) 勤務 (2000 年退社)。2004 年東京工業大学大学院総合理工学研究科博 士後期課程（材料物理科学専攻）修了。科学技術振興機構博士研 究員等を経て、2011 年東京工業大学応用セラミックス研究所准 教授（大学改組により、2016 年から現所属）。主に半導体および 超伝導体の新物質探索とそれらの薄膜成長・デバイス作製に従 事。工学博士。

細 野 秀 雄 1953 年 9 月生。1982 年東京都立大学博士後 期課程（工業化学専攻）修了。1999 年東京工業大学応用セラミ ックス研究所教授。2012 年同大学元素戦略研究センター・セン ター長。酸化物半導体・超伝導体・電子化物・触媒をはじめとす る新材料創製とその応用に関する研究に従事。工学博士。 